Article

\title{
Sustainable Development and Corporate Social Responsibility in Sub-Saharan Africa: Evidence from Industries in Cameroon
}

\author{
Oyewole Simon Oginni ${ }^{1, *}$ and Adewale Daniel Omojowo ${ }^{2}$ \\ 1 Thematic Centre for Governance and Regional Integration, Pan African University, UY II, P.O. Box 18, Soa, \\ Yaounde, Cameroon \\ 2 Faculty of Economics and Management, Department of Environmental Economics, Rural Development and \\ Agric-Business, University of Yaoundé II, P.O. BOX 1365, Soa, Yaounde, Cameroon; danjowo@yahoo.com \\ * Correspondence: simonoginni3@yahoo.com; Tel.: +237-679-177-333
}

Academic Editor: Ralf Fendel

Received: 24 October 2015; Accepted: 3 May 2016; Published: 18 May 2016

\begin{abstract}
Present technological innovations and social organizations continue to impose risks and limitations on the efficient performance of the biosphere. Human activities have increasingly short-lived sustainable natural endowments, to the extent that, the multiplier effects have ripples beyond the traditional benefits of economic production and consumption. Therefore, this study addressed practical concerns on how industries in Sub-Saharan Africa promote sustainable development in their corporate social responsibility models, using industries in Cameroon as a case study; it examined economic, social, and environmental components of sustainable development and corporate social responsibility (CSR). Our sample consists of 335 business enterprises from the last Censure Survey of Enterprises in Cameroon. The study adopted a systematic analysis through the Adjusted Residual Test, and the Phi and Cramer's V tests. Findings revealed that industries in Cameroon prioritize environmental and social dimensions over economic dimensions. However, a few large enterprises implement a broad CSR that promotes sustainable business practices, whereas smaller ones do not; industries in Cameroon implement environmental dimensions of CSR as a safe buffer and a social dimension as philanthropy. Hence, there is no concrete evidence that industries promote sustainable development via CSR in Cameroon. The implementation of a sustainable business model is a precondition for promoting sustainable development via CSR. Industries should realize the concrete value in implementing a sustainable business model that helps to adjust to the complex and increasingly changing business environment.
\end{abstract}

Keywords: corporate social responsibility; externalities; stakeholders; sustainable development

JEL Classifications: O44; O55; Q01; Q56

\section{Introduction}

Present technology innovations and social organizations continue to impose risks and limitations on the efficient performance of the biosphere. Human activities have increasingly short-lived sustainable natural endowments, to the extent that the multiplier effects have ripple beyond the traditional benefits of economic production and consumption. Consequently, the whole planet continues to grapple with climate change, global warming, loss of natural capital assets, and resource scarcities. At the United Nations Conference on Sustainable Development, Rio +20, various international actors emphasized a greater need to channel policy and resources towards sustainable development goals so as to streamline economic activities that impose risks to the environment and fail to reduce poverty level across the world, especially in Africa (United Nations GA Res 21/16, 2012 [1]). 
Even though Rio+20 was not the first conference to address a sustainable development agenda, it did mark a resilient effort to redirect resources and policy towards mitigating against environmental risks and a depletion of natural capital assets as a result of the globalization of economic production and consumption in the 21st century. Thus, sustainable development can be considered as a broad agenda, which aims to channel resources and policy towards addressing present needs, while preserving the ability of future generations to meet their own need (United Nations GA Res. 21/16, 2012 [1]; WBCSD, 2012 [2]).

Evidently, the realization of a sustainable development agenda hinges on realizing concrete values in the economic, political, technological, and cultural spheres. In the economic sphere, business enterprises have pivotal roles to play in order to redirect policy on economic production and consumption activities (WBCSD, 2012 [2]). The reason is that global enterprises manage enormous resources and, therefore, have enormous responsibilities to bear, as global citizens, acting in a socially-responsible manner. The operations of business enterprises should, not only follow a business-as-usual model (an exclusionary profit-maximization goal), but also a broad sustainable business model, capable of improving socio-economic wellbeing, mitigating environmental risks and sustaining natural capital assets. "Industries are not only required to act socially responsible but also to act sustainable in order to meet stakeholders' expectations and promote inclusive growth" (Oginni and Omojowo, 2015 [3]). However, how corporate social responsibility practices should promote sustainable development remains vague in terms of values, principles and norms that guide operations of business activities-profit-maximization syndrome. Hence, there is a need to assess the focus of corporate social responsibility practices of contemporary business enterprises in relation to sustainable development goal of a safe and inclusive growth.

In developed countries, several mechanisms have been adopted to reform the conventional corporate social responsibility models of business enterprises through policy reconstruction and reengineering processes (Centre for Economic and Social Development (CESD), 2013 [4]). For example, the European Commission approved a Green Paper entitled "Promoting a European Framework for Corporate Social Responsibility", in 2001, to promote sound implementation of sustainable business models among industries operating in the Euro zone (European Commission Green Paper, 2001 [5]). Subsequently, the European Commission and its agencies developed policy frameworks (such as the European Commission Commitment of 2 July 2003 [6], the Lisbon European Summit, 2006 [7], and the EC Policy 2012 [8]) on corporate social responsibility for European business enterprises to fully integrate social, ethical, environmental, and human rights concerns into business. These concerted efforts have enhanced the performance of European business enterprises in implementing sustainable business models and a broad corporate social responsibility (Ekins, 2000 [9]). However, in Sub-Saharan Africa, little evidence is available on policy reforms that focus on redefining corporate social responsibility practices among business enterprises to fit a sustainable development agenda (Opondo, 2005 [10]; Corrigan, 2014 [11]). Meanwhile, a consistent economic growth (GDP) rate, celebrated since 2001, in Sub-Saharan Africa has brought about increasing environmental risks and a depletion of natural capital assets from unsustainable economic activities (Economic Commission for Africa/Africa Development Bank/Africa Commission Union, 2014 [12]; United Nations Environment Programme, 2013 [13])

According to the United Nations Environment Programme (2013 [13]), environmental risks constitute 28 percent of Sub-Saharan Africa's disease burden; outdoor air pollution is estimated to kill 800,000 people globally, and about 40,000 of these deaths occur in Sub-Sahara Africa. According to the Africa Progress Panels (2010 [14]), economic growth (Gross Domestic Product) represents the volume of economic activities and, therefore, is not a good indicator of how business activities affect people and the environment. Thus, the contributions of industries to sustainable development agendas via corporate social responsibility need to be assessed on a broader scope: Economic, social and environmental dimensions in Sub-Saharan Africa. The central question is how do industries in Sub-Saharan Africa promote sustainable development via corporate social responsibility practices? Previous studies have extensively focused on corporate social responsibility practices in the mining, 
oil, and gas industries in Zambia, South Africa, and Nigeria (Schrage and Ewing, 2005 [15]; Opondo, 2005 [10]; Amaeshi, Adi, Ogbechie and Olufemi, 2006 [16]; Egels, 2005 [17]; Hamann, 2004 [18]). Therefore, this study excluded mining, oil, and gas industries, and explores agro-allied industries, services sector and other manufacturing industries in Cameroon; it adopts a systematic analysis to address the question of how industries promote sustainable development via corporate social responsibility in Cameroon. In this regard, another question on the intention of implement CSR is addressed: Under what disguise do industries implement CSR practices in Cameroon: To fulfill the requirements of the state laws on CSR, as a strategy to divert attention away from negative impacts of business activities or to promote sustainable development? Other sections are arranged as follows: section two explores the nexus of corporate social responsibility and sustainable development as well as CSR practices among industries in Sub-Saharan Africa; section three explains research methods of the study, section four comprises data analysis and discussion of findings, and the last section (five) deals with conclusion, and recommendations.

\section{Nexus of Corporate Social Responsibilities and Sustainable Development}

Increasingly, the awareness of the destructive consequences of unsustainable practices among business enterprises has drawn a great deal of attention from international actors, policymakers, researchers, and governments, with respect to various aspects of the activities of business enterprises to mitigate environmental risks, to overcome the challenges of resources scarcities, and to promote sustainable development (Corrigan, 2014 [11]). Since corporate social responsibility represents core values that define the commitment of a business enterprise to society, economy, and the environment that sustains its activities, its broad scope can be integrated into a sustainable development agenda. According to the Africa Progress Panels (2010 [14]), it is not the volume of economic activity that determines development, but it is based on how business enterprise activities affect people, economy, and the environment. Therefore, corporate social responsibility appears to further some social good beyond the profit-making existence of business enterprises when a business enterprise conforms to sound ethnics and core values as global citizens and local neighbors in a fast-changing world (McWilliams, 2000 [19]; WBCSD, 2012 [2]; Society for Education and Research Development, 2013 [20]).

However, corporate social responsibility is a subjective and debatable conceptualization; it requires an in-depth analysis in terms of theoretical underpinnings and a complex, increasingly-changing business environment, as well as changing values, principles, and norms of the society to be able to integrate its broad dimensions into a sustainable development agenda. CSR is a subjective concept because societal needs influence the values, principles, and norms attached to corporate social responsibility practices, in the same manner that the development concept received different perspectives in post-World War II, and still receives new perspectives in the 21st century. The conceptualization of corporate social responsibility has changed over time, most notably post-World War II in terms of what should be considered the social responsibility of business (Carroll, 1979 [21]; Freeman, 1984 [22]; Westfield, 2002 [23]; Viser et al., 2010 [24]). Therefore, corporate social responsibility represents a complexion of intricacies that defines the order of preferences between supply-driven and demand-driven stakeholders. The supply side represents the social responsibility of business enterprises to society, and the demand side represents the increased desire for safe, sustainable, and socially responsible contributions from business enterprises (demand-driven). These two competing values are reflected in the conceptualization and contextualization of corporate social responsibility: The ideal that managers should act in the best interest of stockholders, as agents contractually obliged towards wealth-maximization (Friedman, 1962 [25]; Jensen, 2002 [26]; Elhauge, 2005 [27]) and the lack of clarification on how business enterprises should act in a socially responsible way in relation to changing societal values and preferences, as well as increasingly complex business environments (Levitt, 1958 [28]). These account for the lack of agreement between supply-driven and demand-driven stakeholder communities, although the agreement is not important provided that the state policies and laws are flexible and broad enough to adjust to changing societal values. Thus, promoting sustainable 
development via corporate social responsibility might not necessarily require attaining equilibrium between supply-driven and demand-driven society, but it does require an agreement on social costs to be internalized and externalized through policy reconstruction and reengineering processes. This is further discussed via the sustainable business model in the next section.

Further, the realization that the activities of a business enterprise impose social costs on the stakeholder community continues to challenge the traditional firm theory of wealth-maximization and, thus, subject corporate social responsibility concepts to a number of theoretical debates. The three most widely cited theories on CSR in the literature were developed by Friedman (1962 [25], 1970 [29]), Carroll (1979 [21]), and Freeman (1984 [22]), although other theories, such as the resource-based theory, transaction cost theory, ethical theories, and institutional theories, do exist (Pigou, 1920 [30]; Levitt, 1958 [28]; Davis, 1973 [31], Krumsiek, 1997 [32]; Zingales, 2000 [33]; Jensen, 2002 [26]). Levitt (1958 [28]) argues that the responsibilities of private and public sectors should be clearly defined and kept separate in order to promote a society established on freedom and democratic principles that embrace pluralistic system rather than a monolithic system. Levitt (1958 [28]) posits that it is unethical and undemocratic for managers to assume the responsibility of social issues because they are not trained to do so, and any attempt to delve into social issues would lead to 'dire' consequences. Levitt (1958 [28]) was carried away by the fear that business would continue to mold society rather than society molding business if there is no separation of responsibilities between the public and private sectors on social issues. It seems that Levitt's (1958 [28]) position holds true in the 21st century of corporate globalization (Oginni and Moitui, 2016 [34]). Nonetheless, Levitt (1958 [28]) fails to observe that a business enterprise, in of itself, is a social entity; its success depends on social interactions with the environment, which sustain its operations, as well as the stakeholder community.

In addition, it seems that Friedman (1962 [25]) was influenced by Levitt's (1958 [28]) thoughts when he argued that business makes provisions of goods and services, as well creates jobs for society; and that such contributions are sufficient and enough. According to Friedman (1962 [25])there is one, and only one, social responsibility, "to use its resources and engaging in activities designed to increase its profits as long as stays within the rules of the game, which is to engage in free and open competition without deception or fraud". Friedman's argument has been misconstrued in the literature (Walter, 1977 [35]). Clearly, Friedman's main preoccupation is that corporate social responsibility should maximize profits for its stockholders; his position is very clear that business enterprises should engage in the CSR practice only if it is profitable, otherwise, there should be no engagement. However, one important question to address is what constitutes 'the rules of the game'? The rules of the game are a state's laws and policies that regulate the activities of business enterprises. That is, the level of broadness and flexibility of state laws to adjust to changing and complex business environment and societal needs determines the degree to which sustainable development is promoted via corporate social responsibility.

Davis (1973 [31]) provides a flexible approach to corporate social responsibility practices. According to Davis (1973 [31]), business enterprises hold social contracts with society and their existence depends solely on legitimacy within society; if a business enterprise fails to interact with society, then it fails to exist. In the same line, Carroll (1979 [21]) developed a CSR model called the 'pyramid of CSR'. The model was later modified by Carroll (1991 [36], 1994 [37], 1998 [38], 1999 [39], 2000 [40], 2004 [41]) to clarify two competing themes; corporate citizenship and stakeholders. In Carroll's original work, CSR was categorized into four parts: Economic, legal, ethical and discretional responsibilities; and defined CSR as "the conduct of a business so that it is economically profitable, law abiding, ethical and socially supportive". Carroll (1979 [21]) shares same idea as Friedman (1964 [25]), but adopts more broad concepts that received wide empirical use among scholars and practitioners. However, Viser et al., (2010 [24]), reviewing Carroll's CSR pyramid model, contend that Carroll's CSR Pyramid model does not fit into the African context, where there is cultural relativism, a poorly developed legal framework, and a prevalence of poverty. Carroll's model fails to include an environmental dimension that can help to address inherent risks from unsustainable 
business practices across the world; it fails to provide a specific direction on how business enterprises should implement the environmental dimension of CSR.

Further, Freeman (1984 [22]) introduced new and broad perspectives into traditional firm theory through a Stakeholder Theory. Stakeholders' theory emphasizes the interdependence of a business enterprise and its environment by clarifying the concept of stakeholders. According to Freeman (1984 [22]), a stakeholder is "any group or individual who can affect, or is affected by, the achievements of a corporation's purpose. Stakeholders include employees, customer, suppliers, stockholders, bank, environmentalist, government and other groups who can help or hurt the corporation". The exposition of Freeman (1984 [22]) on stakeholders helps in the development of theoretical foundations for contemporary CSR (Zingales, 2000 [33]). According to Jamali (2008 [42]), stakeholders' theory is the most common framework for conceptualizing and understanding issues concerning CSR because it offers a useful basis for collecting and analyzing CSR data, and serves as a framework for empirical studies. Zingales (2000 [33]) also argues that stakeholder theory is a description of the emergence of contemporary firms because it has its foundation in how contemporary firms operate rather than on more confined assumptions of how conventional business enterprises are expected to operate. Therefore, Dahlsrud (2006 [43]) helps to clarify the three dimensions that correspond to sustainable development using five categorizations. These are environmental, social, stakeholder concerned, economic, and voluntary (Table 1).

Table 1. Different dimensions of corporate social responsibility (CSR).

\begin{tabular}{|c|c|c|c|c|}
\hline \multicolumn{5}{|c|}{ CSR Dimensions } \\
\hline Economic & Social & Environmental & Stakeholder & Voluntary \\
\hline $\begin{array}{l}\text { Profit seeking } \\
\text { business } \\
\text { orientation }\end{array}$ & $\begin{array}{l}\text { Public } \\
\text { environment } \\
\text { improvement }\end{array}$ & $\begin{array}{l}\text { Clean } \\
\text { Environment } \\
\text { Security }\end{array}$ & $\begin{array}{l}\text { Relations with } \\
\text { stakeholders } \\
\text { (based on values) }\end{array}$ & $\begin{array}{l}\text { Above and beyond } \\
\text { required by law }\end{array}$ \\
\hline
\end{tabular}

In summary, the increased awareness that activities of business enterprises impose social costs and risks on the environment and stakeholder community has informed policy reconstruction on the model of business activities; it has also helped build new constructs in terms of values, principles, and norms along which the performances of business enterprises in the 21st century can be measured. In the contemporary life of business enterprises, corporate social responsibility is now being conceived in a broader term that touches on economic, social, and environment dimensions of sustainable development. Viser et al. (2010 [44]) explains CSR as the universal concept that modern businesses have obligations towards society, beyond their responsibilities to the investors of the firm.

Therefore, this study defines CSR as intentional and unintentional consequences of business enterprise activities on society. In this regard, CSR seems to incorporate economic, social, and environmental components by creating collective values, principles, and norms that can promote sustainable business practices through policy reconstruction and regulation of the activities of enterprises. The new principles translate collective values via CSR to fit sustainable development agenda. Thus, the continuous demands for sustainable business practices from the stakeholder community can force industries to develop a sustainable business model in order to remain in existence and gain a competitive edge- this defines the nexus between the two concepts. Sustainable business models help to integrate CSR as part of the business development process rather than becoming the outcome of business operations, thereby internalizing externalities and allowing for a flexible approach to address the complex and changing business environment that promotes sustainable development.

Contrary to the traditional firm theory of profit-maximization, contemporary investors have realized the need to assess CSR practices of business enterprises in order to minimize risks to their investments as a result of increasing global demands for sustainable business practices among industries. For example, recent global climate change initiatives have led many investors and 
shareholders to assess the scope of Carbon Disclosure Projects in the CSR of firms as a means of identifying potential threats to a business enterprise's existence and its profitability (Carbon Disclosure Project, 2011 [45]). Through a forward-looking approach, contemporary business enterprises have begun to realize the concrete value in externalizing the costs of greenhouse effects that may presents potentials risks to a business (Mercer, 2011 [46]). The essence of this approach is to help business enterprises adjust quickly to global demands for sustainable practices without necessarily risking their reputations, increasing costs, in the form of penalties, and to remain competitive.

\section{Corporate Social Responsibility Practices in Sub-Saharan Africa (SSA)}

In the late 20th century, there seems to have been a great deal of research on corporate social responsibility of business enterprises in Sub-Saharan Africa. The reasons include: (1) Sub-Saharan African has been vulnerable to environment shocks and social crises more than any other regions in the world (United Nations Environment Programme, 2013 [13]); (2) the region has significant emerging economies with growing market potentials; (3) the challenges of CSR in the region is practically and distinctly different from that of developed countries; and (4) the region is susceptible to the impacts of globalization, foreign direct investment, and increased business activity (World Resources Institute, 2005 [47]). Frequently, a great deal of research carried out on corporate social responsibility in Sub-Saharan Africa has focused on South Africa and Nigeria (Viser, 2003 [48], 2007 [48]) and the broad areas of coverage center around apartheid and colonial ethics, and economic and philanthropic aspects (Schrage and Ewing, 2005 [15]; Opondo, 2005 [10]; Amaeshi et al., 2006 [16]; Egels, 2005 [17]; Hermann, 2004 [18]), but very little of the literature has focused attention on the broad dimensions of corporate social responsibility: Economic, social, and environmental in the region (Blowfield, 2003 [49]; Oginni and Omojowo, 2015 [3]).

According to Centre for Economic and Social Development (2013 [4]), developing countries are more drifted towards economic and philanthropy dimensions of CSR than the environmental dimension because of the immature concept of CSR, high rate of unemployment, and prevalence of poverty, which have influenced the orientation of the philanthropic lifestyle. When a country's motives to promote CSR practices among industries are solely economically motivated, other aspects, such as environmental sustainability and social inclusiveness, may be neglected. However, a country that strives to achieve a sustainable development may focus on policy reforms and reconstruction that promote a sustainable business model and a broad implementation of corporate social responsibility practices (Figure 1). Since business enterprise holds enormous resources which affect social, economic and environmental spheres, it becomes necessary to promote a sustainable business model at the microscopic and macroscopic level of sustainable development (Figure 1). At the micro level, firms implement broad corporate social responsibility practices that balance economic, social, and environmental needs via a sustainable business model. At the macroscopic level, industries strive towards ensuring policy coherence with broad national policies and international best practices on sustainable business practices.

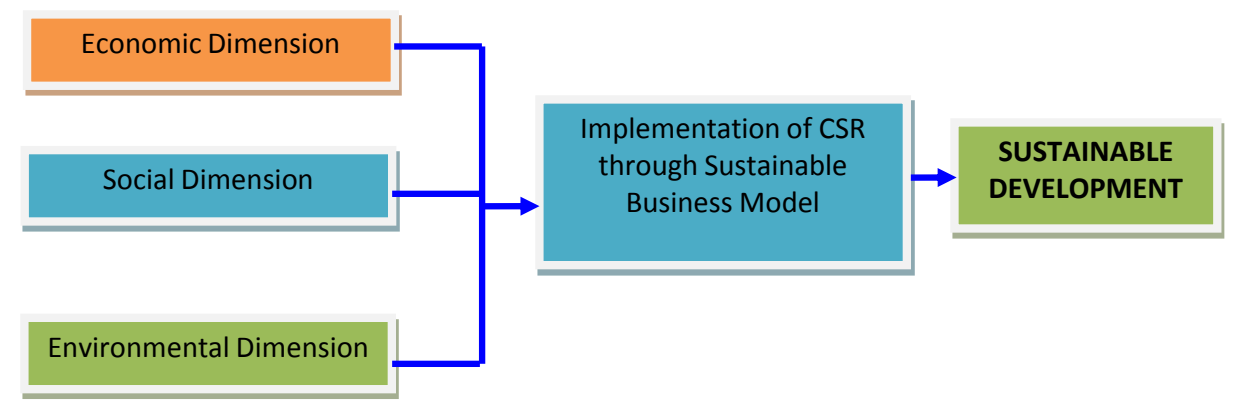

Figure 1. CSR and sustainable development. 
Furthermore, Appelgate and Aman (2001 [50]) propose that sustainable development calls for economic growth that relieves poverty, promotes inclusive growth, and expands environmental resources, based in developing countries. The central question is how can business enterprises, which exist to make profit, implement broad policies to help alleviate extreme poverty in Sub-Saharan Africa? This may require a broad sustainable business model. Bocken, Short, Rana, and Evans (2014 [51]) developed a categorization of sustainable business model archetypes to illustrate the groupings of mechanisms and solutions that might contribute to building up business model innovation for sustainability. Bocken et al. (2014 [51]) explain how business enterprises implement a sustainable business model based on three groupings. The groupings are based on technology, social, and organization, while the archetypes are explained in terms of maximizing material and energy efficiency, creating value from waste, substituting with renewable and natural process, delivering functionality rather than ownership, adopting a stewardship role, encouraging sufficiency, repurposing for society/environment, and develop scale up solutions (Bocken et al., 2014 [51]).

In summary, the development of a sustainable business model helps to integrate corporate social responsibility from the stage of business development; it helps to reduce resource constraints on achieving sustainability in terms of operational costs and potential risks from externalities. The interest of all stakeholders (society and the environment) is broadly and carefully integrated in the development, planning, and the implementation of business operations. Thus, CSR practices are well documented as being part of the business process rather than becoming the outcome of business operations; CSR becomes an input to the strategic goals of business enterprises. Industries, society, and the environment benefit from this broad model for sustainability: CSR becomes integral to sustainable development.

\section{Study Methodology}

This study adopted systematic analysis to assess the level of implementation of the economic, social, and environmental components of sustainable development among business enterprises in Cameroon. A sample of 335 industrial enterprises was drawn from the last Census Survey of Enterprises in Cameroon; these industrial enterprises were selected based on the availability of data on the three dimensions of CSR practices. Data were obtained from the publications of the National Institute of Statistics, Cameroon, from 2009 to 2015. Three dependent variables that correspond to the dimensions of CSR and sustainable development are the social dimension, economic dimension, and environmental dimension, with each being constructed with the help of a proxy. Social dimension data were obtained from the National Social Insurance Fund (NSIF), supplied by the managers of the institutions. The economic dimension variables include tax penalties and fines paid by the selected industries, while the environmental dimension was represented by the amount set aside by these industries for the protection of the environment. Each of these dependent variables is dichotomous (having two modalities: YES or NO). In addition, the independents variables include legal form, activity sector, localization, syndicate, sector of activity, and the presence of a classified installation for the protection of the environment. The coefficient of correlation was used to examine whether the chosen variables are significant or not. By using SPSS version 20, through the Adjusted Residuals cross table, the three dimensions were analyzed. The validity of independent variables is reflected in the results of the Adjusted Residuals and the Phi and Cramer's V tests. Adjusted Residual helps to assess the relationships among the variables and the Phi and Cramer's V tests help to evaluate the variables' level of association to the three dimensions of CSR (economic, social, and environmental). 


\section{Model Specification}

Following Rakotomalala (2008 [52]) ${ }^{1}$, Adjusted Residual was developed using Equations (1)-(3). The difference between the observed and the theoretical chart table was used to construct an indicator: The residue, which explained the nature of the relationship between the terms of the two variables. To determine if the value for the adjusted residual is significant, the absolute value should be greater than 1.96. The residual is built from the relationship:

$$
\begin{gathered}
r s k_{k}=\left(o_{k}-e_{k}\right) \\
r s t d_{l c}=\frac{\left(o_{l c}-e_{l c}\right)}{\sqrt{e_{l c}}} \\
\operatorname{radj}_{l_{c}}=\frac{\left(o_{l c}-e_{l c}\right)}{\sqrt{e_{l c}\left(1-f_{l}\right)\left(1-f_{c}\right)}}
\end{gathered}
$$

To effectuate a bilateral test at $5 \%$, the critical threshold is the order quartile at 0.975 of the centered normal reduced law: $\mathrm{U}_{0.975}=1.96$. When $\left|\operatorname{radj}_{\mathrm{lc}}\right|>1.96$, the relations between the modalities of the variables are attractive $\left(\operatorname{radj}_{l_{c}}>0\right)$, and when $\left(\operatorname{radj}_{l_{\mathrm{c}}}<0\right)$, the relations are repulsive. Attraction means high implication while repulsion means less implication.

Similarly, Cramer's V can be considered as an extension of $\Phi$ from any size of the table. It varies between 0 and 1, no matter the size of the table. It is identical to $\Phi$ for the $2 \times 2$ table. Cramer's V possesses the advantage of depending, neither on the size of the table, nor on the size of the sample (Harald Cramer, 1946). Thus, it is stated as follows:

$$
V=\frac{\chi^{2}}{\sqrt{n \times \min (L-1: C-1)}}
$$

\section{Data Analysis and Results}

Table 2 shows the result of the association test of independent variables employed in the study. The legal form from the Phi and Cramer's V tests is significant at $1 \%$ for the three dimensions of CSR. Similarly, the variable syndicate is significant at $1 \%$ for ENVIRO and ECOS, but not for the social component. Industries equipped with classified installation for the protection of the environment is significant at $1 \%$ for the Phi and Cramer's V tests, except for the social component. Lastly, the variable type of enterprise is significant for all three dimensions of CSR and sustainable development at $1 \%$ and 5\%, respectively. Therefore, the Phi and Cramer's V test table strongly reinforces that legal form; syndicate, environmental equipment, and type of enterprise are good variables for measuring the three dimensions of CSR and sustainable development among industries in Cameroon. The variables adopted correspond to those employed in Poussing (2008 [53]), Poussing and Le Bas (2010 [54]), and Sotamenou (2014 [55]).

1 GERMAN CREDIT $i$ file lists the features of 1000 credits seekers. It contains 23 variables with, among others, the subject of the application for credit (car purchase, HI-FI equipment, etc.), personal status (married, divorced, etc.), employment (skilled, unqualified, etc.). In particular, Rakotomalala is interested in the intersection between the variable "Housing" (Housing-Y), which can take three possible values: For free (no charge to pay: either the person lives in his family, he is an official residence, etc.). Own (owner); rent (tenant) and the variable "Job", which can take four different modalities high qualif/self emp/mgm (in all the management and liberal professions) skilled (skilled labor); unemp/unskilled non res (unemployed, unskilled labour and non-resident); unskilled resident (residents with non-skilled labor). 
Table 2. Test of association (Phi and Cramer's V).

\begin{tabular}{|c|c|c|c|c|c|c|c|c|c|c|c|c|c|c|}
\hline \multicolumn{10}{|l|}{ PHI } & \multicolumn{5}{|c|}{ CRAMER'S V } \\
\hline \multirow[t]{2}{*}{ FAC_ADOP } & \multicolumn{2}{|l|}{ ENVIRO } & \multicolumn{3}{|c|}{ SOCIAL } & \multicolumn{4}{|l|}{ ECOS } & \multicolumn{3}{|c|}{ ENVIRO } & SOCIAL & \multirow{2}{*}{$\begin{array}{l}\text { ECOS } \\
\text { App } \\
\text { Sig } \\
\end{array}$} \\
\hline & Val Ap. Sig. & $\varnothing_{\max }$ & Val & AP. Sig. & $\varnothing_{\max }$ & Val & Ap. Sig & $\varnothing_{\max }$ & Val & Ap. Sig & Val & App Sig & Val & \\
\hline Legal form & $0.25 \quad 0.00^{* *}$ & 1 & 0.25 & $0.00^{* *}$ & 1 & 0.27 & $0.00^{* *}$ & 1 & 0.25 & $0.000^{* *}$ & 0.255 & $0.000^{* *}$ & 0.271 & $0.00^{* *}$ \\
\hline Syndicate & $-0.180 .002^{* *}$ & 1 & -0.01 & 0.81 & 1 & 0.27 & $0.00^{* *}$ & 1 & 0.18 & $0.002^{* *}$ & 0.014 & 0.809 & 0.276 & $0.00^{* *}$ \\
\hline $\begin{array}{l}\text { Industries equipped } \\
\text { with classified } \\
\text { installation }\end{array}$ & $-0.580 .00^{* *}$ & 1 & -0.06 & 0.06 & 1 & 0.15 & $0.00^{* *}$ & 1 & 0.58 & $0.00^{* *}$ & 0.058 & 0.296 & 0.157 & $0.007^{* *}$ \\
\hline Type of enterprise & $0.3500 .000^{* *}$ & 1 & 0.147 & 0.076 & 1 & 0.287 & $0.00^{* *}$ & 1 & 0.350 & $0.000^{* *}$ & 0.147 & 0.076 & 0.287 & $0.00^{* *}$ \\
\hline
\end{tabular}

ENVIRO: Environment; ECOS: Economic; Meaning: val = value, App sig = approximate significance, $p=0.01$ ** 
Furthermore, Table 3 shows the results from the adjusted residual test. The adjusted residual table shows the relationships that exist between the dependent variable of the three dimensions of CSR and the modalities of the variables. From the table, only modalities of which the absolute value is greater than 1.96 are significant. The negative sign shows repulsive (meaning less implication) while the positive sign shows attraction (meaning high implication).

Table 3. The adjusted residual cross table of three dimensions of CSR and variables: Dependency relation.

\begin{tabular}{|c|c|c|c|c|c|c|}
\hline \multicolumn{7}{|c|}{ Corporate Social Responsibility Factors of Adoption } \\
\hline \multirow{2}{*}{$\begin{array}{l}\text { Description of } \\
\text { Variables }\end{array}$} & \multicolumn{2}{|c|}{ Environment } & \multicolumn{2}{|c|}{ Social } & \multicolumn{2}{|c|}{ Economic } \\
\hline & No & Yes & No & Yes & No & Yes \\
\hline \multicolumn{7}{|c|}{ Legal Form } \\
\hline $\begin{array}{l}\text { Limited Liability } \\
\text { Company }\end{array}$ & $36(-4.3)$ & $24(4.3) *$ & $2(-2.3)$ & $67(2.3) *$ & $46(4.1)$ & $18(-4.1)^{*}$ \\
\hline \multicolumn{7}{|c|}{ Syndicate } \\
\hline Yes & $46(-3.1)$ & $23(3.1) *$ & $7(-0.2)$ & $66(0.2)$ & $50(4.7)$ & $17(-4.7) *$ \\
\hline No & $197(3.1)$ & $38(-3.1) *$ & $26(0.2)$ & $220(-0.2)$ & $94(-4.7)$ & $131(4.7) *$ \\
\hline Total & 243 & 61 & 33 & 286 & 144 & 148 \\
\hline \multicolumn{7}{|c|}{ Industries Equipped with Classified Installation } \\
\hline Yes & $\begin{array}{c}32 \\
(-10.2)\end{array}$ & $47(10.2) *$ & $6(-1.0)$ & $76(1.0)$ & $47(2.7)$ & $28(-2.7) *$ \\
\hline No & $211(10.2)$ & $14(-10.2)$ * & $27(1.0)$ & $210(-1.0)$ & $97(-2.7)$ & $120(2.7)$ * \\
\hline Total & 243 & 61 & 33 & 286 & 144 & 148 \\
\hline \multicolumn{7}{|c|}{ Type of Enterprise } \\
\hline Big Enterprise & -6.1 & 6.1 * & -1.4 & 1.4 & 3.6 & $-3.6^{*}$ \\
\hline
\end{tabular}

Results from the adjusted residual cross table (Table 2) show that Limited Liability Companies (LLC) practice all three dimensions of CSR and sustainable development (i.e., environment, social, and economic dimensions) at 4.3, 2.3, and -4.1. The negative result obtained from the economic dimension (-4.1) signifies that, though LLCs practice CSR, this practice is repulsive (that is, it has less implication) compared to the social and environmental dimensions, which are attractive (high implication). It is implied that LLCs adopt all the three dimensions of CSR, but that the level of implementation differs from one dimension to the other.

Moreover, test results under syndicate (Table 2) emphasize the environmental and economic dimensions of CSR at 3.1 and -4.7 , respectively, while the social dimension (0.2) was insignificant $(<1.96)$. This implies that social wellbeing of workers is not emphasized in the implementation of CSR under syndicate, as a result of the poor regulatory framework on social security among industries in Cameroon. The same result was obtained for enterprises with a classified installation for environmental protection, except that the environment dimension is more emphasized (10.2) than the economic dimension (-2.7). Lastly, for the type of enterprise, LLCs of a large size seem to implement the environmental dimension of CSR (6.1) rather than the economic dimension (-3.6), which is repulsive. This implies that large-sized industries have enough resources to implement sound CSR practices for the environment whereas the smaller ones do not.

\section{Discussion of Findings}

Analyzing sustainable development via the corporate social responsibility of industries in Cameroon provides interesting evidence. Sustainable development was analyzed in terms of economic, social, and environmental elements of CSR. Business enterprises were classified based on three 
categories: Legal form, syndicate, and environmentally-friendly enterprises. The test results show that the legal form, syndicate, and industries equipped with a classified installation could provide adequate assessment of the economic, social, and environmental dimensions of CSR of industries in Cameroon. The adjusted residual test results on the implementation of CSR among Limited Liability Companies (LLC) show that LLCs are more focused on environmental and social dimension of CSR rather than the economic aspects. The same result was obtained for syndicate and industries with classified installations for environmental protection. The findings have three implications. First, pressures from government of Cameroon to comply with various environmental laws might influence increased concentration on the environmental aspect of CSR among industries operating in the country (Sama, 2015 [56]). In recent times, the government of Cameroon has reformed environmental laws to ensure that industries comply with international best practices on CSR (EIA, 2013 [57]). Therefore, industries have been forced to implement CSR in accordance with applicable environmental laws. Contrary to Carroll's CSR Pyramid, which prioritizes economic responsibilities as a precondition to other responsibilities, industries in Cameroon promote environmental dimensions of CSR rather than the economic dimension. The reason for this is very simple: CSR is still being implemented in line with traditional theory of profit-maximization, which emphasizes compliance with laws to remain socially responsible, as well as regarding CSR as a non-commercial activity (Levitt, 1958 [28], Freeman, 1984 [22]; Jensen, 2002 [26])

Second, the negative value obtained for the economic dimension of CSR suggests that business enterprises have not recognized the concrete value in implementing broad CSR for a competitive advantage. The result of findings of this study validate Viser et al. (2010 [24]), who contend that Carroll's CSR Pyramid order of dependence is not applicable to Sub-Saharan Africa. However, the result does not conform to Centre for Economic and Social Development (2013) [4], which argued that industries in developing countries are more affected by economic and philanthropic dimensions of CSR than by the environmental dimension, because of the immature concept of CSR, high rate of unemployment, and prevalence of poverty, which have influenced the orientation of the philanthropic lifestyle.

Over the years, the increasing awareness of the destructive consequences of unsustainable business practices in developing countries has influenced continuous pressures on industries to comply with international best practices that promote a sustainable business model. This is the reason that industries in Cameroon implement CSR to meet the requirements of law, and not as a strategy to gain a competitive edge. In addition, the philanthropic culture of Africans requires that a limited scope of social dimension of CSR be implemented in order to remain competitive. According Davis (1973 [31]), interdependence of business enterprises and society is necessary to remain profitable. Therefore, having recognized the philanthropic culture of Africa (Viser et al., 2010 [24]), industries in Cameroon seem to implement a limited scope of a social dimension of CSR (as philanthropy) to distract the attentions of the public away from a broad social dimension that ought to be implemented. However, the scenario is different in many developed countries where citizens' demand for sustainable business practices among industries is growing. Many EU Member States have compelled industries, operating in the region, to implement broad CSR practices via sustainable business models (Appelgate, 2001; Mercer, 2011 [50]). Consequently, industries in the region have realized a concrete value in implementing broad CSR practices via sustainable business models in order to remain competitive in the market and to avoid incidental costs of unsustainable business practices (CDP, 201 [45]). Hence, it is difficult to establish a connection between CSR and sustainable development in the case of Cameroon. Notwithstanding, the last finding of the study reveals that large-sized business enterprises implement environmental dimension of CSR as opposed to smaller ones. Perhaps, government laws and policies on sustainable development have not been localized to integrate the activities of smalland medium-scale enterprises into the development cycle. 


\section{Conclusions and Recommendations}

In the recent times, sustainable development has occupied both national and international agenda. The reason for this is that the achievement of sustainable development hinges on realizing concrete values in the economic, political, technological, and cultural spheres. In the economic sphere, business enterprises have pivotal roles to play in order to redirect policy on unsustainable business practices, which have continued to impose social costs and risks to society and the environment. Consequently, there have been increased global demands from society that industries should act in a socially responsible way by implementing sustainable business practices. In developed world, there has been evidence of industries implementing broad corporate social responsibility via a sustainable business model that integrates the economic, social, and environmental dimensions of sustainable development. In Sub-Saharan Africa, little evidence exists on a nexus of corporate social responsibility and sustainable development. Therefore, the central question is: How do contemporary industries promote sustainable development via corporate social responsibility practices in Sub-Saharan Africa? To address this concern, a contextualized concept of corporate social responsibility is used in terms of values, principles, and norms to promote the drive for a sustainable development in Sub-Saharan Africa. In other words, the societal values, principles, and norms are being streamlined, along the continuum that industries impose social costs and risks to the environment and society. Since these values, principles, and norms differ according to the perceived needs for sustainable development (mitigation of environmental risks, preservation of natural capital assets, promotion of inclusive growth, and poverty alleviation), corporate social responsibility is addressed from broad perspectives that touch on economic, social, and environmental aspects of sustainable development in Sub-Saharan Africa. It is argued that the implementation of a sustainable business model among industries is sine qua non, a precondition for implementing sound corporate social responsibility practices, which can promote sustainable development in Sub-Saharan Africa.

Further, this study examined how industries promote sustainable development via corporate social responsibility practices in Cameroon. The central question is: To what extent have business enterprises promoted sustainable development via corporate social responsibility in Cameroon? The result of our findings indicates that industries in Cameroon implement only two dimensions of sustainable development: The environment dimension (as a safe buffer) and the social dimension (as philanthropy); large enterprises implement the environmental dimension of CSR more than the smaller ones. Industries in Cameroon have not realized a concrete value in implementing CSR to gain a competitive advantage. However, it seems that state laws and policies on sustainable business practices in Cameroon focus mainly on large enterprises, which accounts for why small business enterprises have little concern for environmental protection. Hence, there is no concrete evidence that industries promote sustainable development via CSR in Cameroon. However, there is a growing awareness on the environmental risks and social costs of unsustainable business practices among industries in the country because many of them have environment friendly installations to mitigate environmental risks. Therefore, state laws and policies should promote a sustainable business model; there is a need to reform policies on business activities to promote sustainable development from small and medium enterprises to large enterprises.

Acknowledgments: The authors thank the three anonymous referees for their constructive comments and suggestions.

Author Contributions: Both authors contributed equally.

Conflicts of Interest: The authors declare no conflicts of interest. 


\section{References}

1. United Nations. Report of the United Nations Conference on Sustainable Development. Rio de Janeiro, Brazill, 20-22 June 2012. Available online: http:/ / docbox.un.org/DocBox/docbox.nsf/GetFile?OpenAgent\& DS=A/CONF.216/16\&Lang=E\&Type=DOC (accessed on 1 September 2015).

2. WBCSD. Roi +20 and Beyond. WBCSD Regional Network. 2012. Available online: http://wbcsdservers.org/ wbcsdpublications/cd_files/datas/international_relations/global_network/pdf/RN-Rio20\%20and\%20 beyond.pdf (accessed on 1 September 2015).

3. Oginni, O.S.; Omojowo, A.D. The Implementation of Sustainable Business Model among Industries in Cameroon. OIDA Int. J. Sustain. Dev. 2015, 8, 71-80.

4. CESD (Center for Economic and Social Development). Achieving Sustainable Development through Corporate Social Responsibility. Available online: http://www.iz.or.at/images/doku/csr_research_paper_ cesd_kas.pdf (accessed on 9 September 2015).

5. Commission of the European Communities. Green Paper: Promoting a European Framework for Corporate Social Responsibility; Commission of the European Communities: Brussels, Belgium, 2001.

6. Sustainable Forestry and the European Union. Initiatives of the European Commision. European Communities: Luxembourg, Belgium, 2003. Available online: http://ec.europa.eu/agriculture/publi/ brochures/forestry/full_en.pdf (accessed on 10 September 2015).

7. Council of the European Union. Brussels European Council 23/24 March 2006. Presidency Conclusions. Available online: http://www.consilium.europa.eu/ueDocs/cms_Data/docs/pressData/en/ec/89013.pdf (accessed on 10 September 2015).

8. Council of the European Union. Council Conclusions: "Increasing the Impact of EU Development Policy: An Agenda for Change". 3166th FOREIGN AFFAIRS Council Meeting, Brussels, 14 May 2012. Available online: http:/ / www.consilium.europa.eu/uedocs/cms_data/docs/pressdata/EN/foraff/130243.pdf (accessed on 10 September 2015).

9. Ekins, P. Economic Growth and Environmental Sustainability: The Prospects for Green Growth; Routledge: New York, NY, USA, 2000.

10. Opondo, M. Emerging Corporate Social Responsibility in Kenya's Cut Flower Industry. University of Nairobi, Department of Geography and Environmental Studies: Nairobi, Kenya; 2005. Available online: http://www.unisa.ac.za/contents/colleges/col_econ_man_science/ccc/docs/Opondo.pdf (accessed on 10 September 2015).

11. Corrigan, T. Area in the Country Review Reports on Lesotho, Mauritius, Mozambique, South Africa, Tanzania and Zambia; South Africa Institute of International Affairs: Johannesburge, South Africa, 2014.

12. Economic Commission for Africa/AfDB/AUC. Assessing Progress in Africa toward the Millennium Development Goals: Analysis of the Common African Position on the Post-2015 Development Agenda, MDG Report; Economic Commission for Africa: Addis Ababa, Ethiopia, 2014.

13. Africa Environmental Outlook 3: Our Environment, Our Health, Summary for Policymakers. Available online: http:/ / www.unep.org/pdf/aeo3.pdf (accessed on 10 September 2015).

14. Africa Progress Panels. From Agenda to Action: Turning Resources into Results for People. Africa Progress Report 2010. Available online: http://app-cdn.acwupload.co.uk/wp-content/uploads/2013/08/2010_ APR_From_Agenda_to_Action_APR_2010_ENG.pdf (accessed on 5 August 2015).

15. Schrage, E.J.; Ewing, A.P. The Cocoa Industry and Child Labour. J. Corp. Citizsh. 2005, 18, 99-112. [CrossRef]

16. Amaeshi, K.M.; Adi, B.C.; Ogbechie, C.; Olufemi, O.A. Corporate Social Responsibility in Nigeria: Western Mimicry or Indigenous Influences? J. Corp. Citizsh. 2006, 24, 83-99. [CrossRef]

17. Egels, N. CSR in Electrification of Rural Africa: The Case of ABB in Tanzania. J. Corp. Citizsh. 2005, 18, 75-85. [CrossRef]

18. Herrmann, K.K. Corporate Social Responsibility and Sustainable. Glob. J. Manag. Bus. Stud. 2004, 3, 681-688.

19. McWilliams, A.D. Corporate Social Responsibilities and financial performance. Strateg. Manag. J. 2000, 21, 603-609. [CrossRef]

20. Society for Education and Research Development. Sustainable Development. 2013. Available online: http:/ / serd.org.in/csr2013/ (accessed on 1 September 2015).

21. Carroll, A.B. A three-dimensional conceptual model of corporate social performance. Acad. Manag. Rev. 1979, 4, 497-506. 
22. Freeman, R.E. Strategic Management: A Stakeholder Approach; Pitman: Boston, MA, USA, 1984.

23. Westfield, E. Globalizations, Governance, and Multinational Enterprise Responsibility Corporate. Codes of Conduct in the 21st Century. J. Int. Law 2002, 10, 1084-1085.

24. Visser, W.; Dirk, M.; Pohl, M.; Tohurst, N. The A to Z of Corporate Social Responsibility; ICCA Publication, John Willey \& Sons Ltd.: West Sussex, UK, 2010.

25. Friedman, M. Capitalism and Freedom; The University of Chicago Press: Chicago, IL, USA; 1962.

26. Jensen, M.C. Value maximization, stakeholder theory, and the corporate objective function. Bus. Ethics Q. 2002, 12, 235-256. [CrossRef]

27. Elhauge, E. Sacrificing Corporate Profits in the Public interest. N. Y. Univ. Law Rev. 2005, 80, 733-869.

28. Levitt, T. The dangers of social responsibility. Harv. Bus. Rev. 1958, 36, 41-50.

29. Friedman, M. The Social Responsibility of Business Is to Increase its Profits. New York Times, 13 September 1970; 122-126.

30. Pigou, A.C. The Economics of Welfare; Macmillan: London, UK, 1920.

31. Davis, K. Case for and against business assumption of social responsibilities. Acad. Manag. J. 1973, 16, 312-322. [CrossRef]

32. Krumsiek, B.J. The emergence of a new era in mutual fund investing: Socially responsible investing comes of age. J. Invest. 1997, 6, 25-30. [CrossRef]

33. Zingales, L. In search for new foundations. J. Finance 2000, 55, 1623-1653. [CrossRef]

34. Oginni, S.O; Moitui, J.N. African Renaissance and Pan-Africanism, a Shared Value and Identity among African Nationals. Africology J. Pan Afr. Stud. 2016, 9, 39-58.

35. Walters, K.D. Corporate social responsibility and political ideology. Calif. Manag. Rev. 1977, $19,40-51$. [CrossRef]

36. Carroll, A.B. The Pyramid of Corporate Social Responsibility: Toward the Moral Management of Organizational Stakeholders. Bus. Horiz. 1991, 34, 39-48. [CrossRef]

37. Carroll, A.B. Social issues in management research: Experts' views, analysis and commentary. Bus. Soc. 1994, 33, 5-29. [CrossRef]

38. Carroll, A.B. The Four Faces of Corporate Citizenship. Bus. Soc. Rev. 1998, 100, 1-7. [CrossRef]

39. Carroll, A.B. Corporate social responsibility. Bus. Soc. 1999, 38, 268-295. [CrossRef]

40. Carroll, A.B. Ethical Challenges for Business in the New Millennium: Corporate Social Responsibility and Models of Management Morality. Bus. Ethics Q. 2000, 10, 33-42. [CrossRef]

41. Carroll, A.B. Managing Ethically With Global Stakeholders: A Present and Future Challenge. Acad. Manag. Exec. 2004, 18, 114-120. [CrossRef]

42. Jamali, D.; Safieddine, A.M.; Rabbath, M. Corporate Governance and Corporate Social Responsibility Synergies and Interrelationships. Int. Rev. 2008, 15, 443-459. [CrossRef]

43. Dahlsrud, A. How Corporate Social Responsibility is Defined: An Analysis of 37 Definitions. Corporate Social Responsibility and Environmental Management. Corp. Soc. Responsib. Environ. Manag. 2006, 15, 1-13. [CrossRef]

44. Visser, W. Revisiting Carroll's CSR Pyramid: A Short Review of the Historical Critique of Usury. Account. Bus. Financ. His. 2007, 8, 175-189. [CrossRef]

45. CDP. CDP Global 500 Report 2011; Carbon Disclosure Project: London, UK, 2011.

46. Mercer, L.L. Climate Change Scenarios-Implications for Strategic Asset Allocation; Mercer LLC, Carbon Trust, International Finance Corporation: London, UK, 2011.

47. WRI. The Wealth of the Poor: Managing Ecosystems to Fight Poverty; World Resources Institute: Washington, DC, USA, 2005.

48. Visser, W. Corporate Responsibility in a Developing Country Context. Available online: http:// www.waynevisser.com/wp-content/uploads/2012/07/article_myths_devcos_wvisser.pdf (accessed on 1 April 2016).

49. Blowfield, M. Ethical Supply Chains in the Cocoa, Coffee and Tea Industries. Greener Manag. Int. 2003, 43, 15-24. [CrossRef]

50. Appelgate, J.S.; Aman, A.C. Introduction: Syncopated Sustainable Development. J. Glob. Leg. Stud. 2001, $1,3-4$.

51. Bocken, N.M.P.; Short, S.W.; Rana, P.; Evans, S. A literature and practice review to develop sustainable business model archetypes. J. Clean. Prod. 2014, 65, 42-56. [CrossRef] 
52. Rakotomalala, R. Etude des Dependances-Variables Qualitatives Tableau de Contingence et Mesures Diassociation; Université Lumière Lyon 2; 2008; Available online: http://eric.univ-lyon2.fr/ \{\}ricco/cours/cours/ Analyse_de_Correlation.pdf (accessed on 1 September 2015).

53. Poussing, N. Les determinant de l'adoption de la Responsabilite Sociale des entreprise. Commun. Colloq. En Route Pour Lisbon 2008, 12, 17.

54. Le Bas, C.; Poussing, N. Les Comportement de l'Innovation et de Responsabilite Sociale Sont Lies. Une Analyse Empirique sur des Donnes Luxembourgeoises. Available online: http:/ /www.strategie-aims.com/ events/conferences / 2-xixeme-conference-de-l-aims / communications/27-les-comportements-dinnovationet-de-responsabilite-sociale-sont-lies-une-analyse-empirique-sur-des-donnees-luxembourgeoises/download (accessed on 1 April 2016).

55. Sotamenou, J. Corporate social responsibility among small and medium size enterprises in Cameroon. J. Entrep. Innov. Manag. 2014, 3, 1-19.

56. Sama, N.J. Compliance \& Enforcement of Environmental Law in Cameroon. In Proceedings of the Second Africa-Asia Inter-Regional Expert Meeting on Environmental Enforcement, Kunming, China, 1-4 December 2015.

57. EIA. Environmental and Social Impact Assessment. Cameroon Association for the Environmental Assessment; Yaounde, Cameroon; 2013. Available online: http:/ /www.eia.nl/en/countries/af/cameroon/ eia (accessed on 9 September 2015).

(C) 2016 by the authors; licensee MDPI, Basel, Switzerland. This article is an open access article distributed under the terms and conditions of the Creative Commons Attribution (CC-BY) license (http://creativecommons.org/licenses/by/4.0/). 